This is the accepted version, before publication, of

Pettersson, K., Ahl, H., Berglund, K., \& Tillmar, M. (2017). In the name of women? Feminist readings of policies for women's entrepreneurship in Scandinavia. Scandinavian Journal of Management, 33(1), 50-63.

\title{
In the name of women? Feminist readings of policies for women's entrepreneurship in Scandinavia
}

Katarina Pettersson, Swedish University of Agricultural Sciences, Department of Urban and Rural Development, P.O. Box 7012, SE-750 07 Uppsala, Sweden

Helene Ahl, Jönköping University, School of Education and Communication, Sweden

Karin Berglund, Stockholm Business School at Stockholm University, Sweden

Malin Tillmar, Linneaus University, School of Business and Economics, Department of Organization and Entrepreneurship and Linköping University, Department of Management and Economics and Helix Competence Centre, Sweden

Keywords: Feminist approach, Women Entrepreneurship policy, Scandinavia

\section{Introduction}

The recognition of new ventures as the 'engine of economic development' (Birch, 1979; McCloskey, 2010) has motivated much research on entrepreneurship (Davidsson \& Wiklund, 2001; Ahl, 2006) as well as research on entrepreneurship policy (Acs \& Szerb, 2007; Audretsch, Grilo, \& Thurik, 2007). As a consequence of its importance to economic development, actors at various geographic and policy levels seek to promote entrepreneurship (for example, the IEG World Bank Group, 2013), and, sometimes, lend special attention to women and entrepreneurship (for example, the European Commission, 2013). The reasons for this special attention vary, but have included: (i) women are an unused resource for economic development; (ii) women and men should be supported to an equal extent; and (iii) there is a need for a support system that is more gender equal.

It is not given, however, that policy initiatives for women entrepreneurs necessarily contribute to gender equality, to social change for women - such as enhancing entrepreneurship as a means to women's well-being and financial or other independence - or to gendered change of society. We claim that the outcomes depend on the premises behind the policies. For example, whether the policy is feminist, or not, and whether it seeks to improve women's standing in society, or not. And, if the policy is actually feminist, the outcomes of the policy may depend on which kind of feminist perspective informs the policy and its implementation. A liberal feminist approach, for example, will focus on equal opportunities, whereas a socialist feminist approach may address the gendered divisions of labour.

The purpose of this paper is to conduct an analysis of the feminist approaches that are taken in policies for women's entrepreneurship in the Scandinavian countries. We analyse how these policies argue for women's entrepreneurship, how they position women, and what assumptions 
they hold with respect to women and their businesses. We analyse and compare state-level polices that have been implemented by the national governments in three Scandinavian countries; Denmark, Norway, and Sweden, during the period 2005-2015.

The article does not investigate gender equality per se, but rather it investigates the image of Scandinavian countries as being the most gender-equal in the world, and gender-equal in similar ways (for example, UNdata, 2012). By comparing policies on women's entrepreneurship, we are able to identify similarities as well as differences between the countries.

Our study is situated within a post-structuralist feminist approach which enables an analysis of how entrepreneurship concepts, theories, and practices construct gender and position women (Calás, Smirchic, \& Bourne, 2007). It views language and texts (e.g. policy documents) as producing gender and allows for an analysis of how social orders are gendered and of how (women and men) entrepreneurs are represented. The post-structuralist approach is congruent with the assumption made in policy framing analysis, namely: "that a policy (proposal) will always contain an implicit or explicit representation of a diagnosis, connected to an implicit or explicit prognosis and a call for action” (Verloo, 2005:22).

We develop and employ a novel analytical tool using an array of feminist theoretical lenses, responding to Ahl's (2006) call for gender research on support systems for entrepreneurs. The analytical tool was developed by 'translating' the outlines of six different feminist theoretical perspectives on organizations, which in various ways seek social change for equal societies, as developed by Calás and Smirchic (1996), and Calás, Smirchic, \& Bourne (2007; 2009) (see Table 1). We supplement this tool with an element of 'visual analysis', as called for by Galloway, Kapasi, \& Sang (2015). Our analytical tool is the first contribution made by the present paper. The second contribution is the application of the tool and a concurrent, comparative, feminist examination of state policies for women's entrepreneurship in the Scandinavian countries. We reveal the feminist approaches that are used (or not used) and how women are positioned in the relevant policies. These two things can guide future research, allow for the posing of new research questions, and enable policy makers to formulate and critically evaluate policy proposals.

The paper is organized as follows. The following section presents the theoretical background. It includes a discussion of the presence, or rather absence of feminist theory in research on women's entrepreneurship, a definition of feminist approaches to entrepreneurship, an overview and analysis of policy for women's entrepreneurship, and an overview of gender (in)equality in Scandinavia. Next we describe our material and research method, including the analytical tool that we developed for the purpose at hand. We subsequently present our policy analysis, country by country. The results are then presented and discussed comparatively. The paper ends with a summary of our conclusions. 


\section{Theoretical background}

The absence of feminist theory in research on women's entrepreneurship

Women's entrepreneurship became a scholarly issue in the early 1980s. Early studies were largely descriptive, and were typically cast in a 'gender comparative' framework. Women were found to be underrepresented as business owners, and were concentrated in the service sector (care and retail). Women ran, on average, smaller, less profitable, and more slowly growing businesses than men (Brush, 1992; Hisrish \& Brush, 1984; Sundin \& Holmquist, 1989). Women's so-called 'under-performance' was then a problem that needed to be explained. We find some traces of liberal feminist theory (which claims that women's subordination is due to discrimination) in studies that claim that discrimination by loan officers is a reason, for this 'under-performance'; but such discrimination has not been confirmed (Coleman, 2000; Fabowale, Orser, \& Riding, 1995). Most other studies focused on the personal traits of women entrepreneurs; hypothesizing that women had less capacity for entrepreneurship than men, but again, few, if any, gender differences were found (Ahl, 2004). The 'personal trait' approach has subsequently been abandoned by entrepreneurship scholarship at large (Gartner, 1988), but the notion of essential gender differences appears more difficult to relinquish. In fact, the research field is itself gendered (Ahl, 2006; Bruni, Gherardi, \& Poggio, 2004a; Ogbor, 2000). The idea of the heroic male entrepreneur is often the unspoken benchmark (Nicholson \& Anderson, 2005). Research on women's entrepreneurship which does not use a feminist perspective thus tends to position women as the 'other' in relation to men entrepreneurs, thereby reproducing a male norm (Ahl, 2006; Bruni, Gherardi, \& Poggio, 2004b; Calás, et al., 2007), which, in turn, exaggerates the perceived differences between men and women entrepreneurs (DuRietz \& Henrekson, 2000).

In spite of recent calls for the contextualization of women's entrepreneurship (Welter, 2011), the most comprehensive review of the research field to date reveals that the great majority of research remains empiricist; based on comparisons between men and women, rather than challenging gendering practices (Jennings \& Brush, 2013). Explicit references to feminist theory are, for the most part, absent in the literature on women's entrepreneurship - only in the most recent decade have articles using post-structuralist feminist theory appeared in entrepreneurship research journals (for example Ahl, Berglund, Pettersson, \& Tillmar, 2016; Henry, Foss, \& Ahl, 2015).

\section{Feminist approaches to (women's) entrepreneurship}

Feminist approaches recognize male dominance in social arrangements and want to change this domination (Calás \& Smircich, 1996). Feminist approaches seek social change to achieve just and egalitarian societies (Calás, Smircich, \& Bourne, 2007) and are thus critical of the status quo. Feminist approaches are thus always political (Calás \& Smircich, 1996). However, it is noted that: "the degree of critique and the nature of the politics vary across feminist theoretical knowledge” (Calás, Smircich, \& Bourne, 2007:79). Table 1 summarizes two outlines of feminist approaches to entrepreneurship (Calás \& Smircich, 1996; Calás, Smircich, \& Bourne, 2007). 


\section{Table 1. Feminist approaches to entrepreneurship}

\begin{abstract}
Liberal feminist theory sees men and women as essentially similar, equally capable, and as rational human beings. It builds on $19^{\text {th }}$ Century liberal political theory which envisioned a just society as one where everyone can exercise autonomy through a system of individual rights. Liberal feminism has aimed for equal property and legal rights, women's suffrage, and equal access and representation. Liberal feminist theory explains any differences between men and women's achievements by organizational or societal discrimination. Research, (including research on entrepreneurship), that is conducted within this theoretical framework thus investigates barriers, like a lack of access to resources. But focus is often directed towards differences between men and women (including demographic, behavioural, and cognitive differences), instead of problematizing institutional practices. Even though liberal theory purports to represent all 'women', the typical woman is white, middle-class, and heterosexual.
\end{abstract}

Radical feminist theory can be characterized as a feminism of 'difference'. It takes the subordination of women as its point of departure and views patriarchal structures as a system of male domination. The subordination of women is due to male privilege and power, and men and women are seen as essentially different. The approach is women-centred, and includes consciousness-raising and proposes alternative (and sometimes separatist) social-, economic-, and political arrangements which challenge the conditions of a maledominated society.

Psychoanalytic approaches imply an appreciation of women and men's unique sex-role socialization. In women's entrepreneurship, focus is placed on certain traits, like a 'feminine ethics of care'. These approaches claim that the patriarchal family and educational system produce unequal gender development and disparage female traits. Psychoanalytical feminism views women's unique sex-role socialization and their different traits as advantages for organizations.

Socialist feminist theory implies an analysis of the relations of power and inequality within a capitalist economy. The gendered divisions of labour are of concern in this theoretical approach. Critical studies of men and masculinities, and intersectional analyses are addressed, including the 'doing gender approach'. Research practices within this approach ask how 'doing gender' might also be characterized as 'doing entrepreneurship'.

Post-structuralist/post-modern feminist approaches are concerned with language as a system of difference. Texts and language are seen as a 'politics of representation' that produces gender. Universal and objective knowledge claims, and related epistemologies, are called into question. Deconstructive studies that employ these approaches analyze concepts, theories, and practices of entrepreneurship, and how they construct (women) entrepreneurs.

Post-colonial feminist theories critique Western feminist approaches, and question the privileging of white, heterosexual, middle-class representations of gender. Post-colonial feminist theories investigate the function of 'the nation' in gendering and racializing 'others'. Entrepreneurship could be called into question, as it has become a mantra for economic development, following a Western neoliberal recipe for such development.

Sources: After Calás \& Smircich (1996) and Calás, Smircich, \& Bourne (2007). 
Calás, Smircich, and Bourne (2007) cluster these approaches into two groups. The first group, liberal-, radical, and psychoanalytic approaches, is focused on women and entrepreneurship, and are based on an ontological assumption that women are disadvantaged because of their condition as women. This first group focuses on women's 'sameness' (with respect to each other) and women's difference from men. In this perspective, gender refers to specifically 'sexed' bodies. In contrast, the second group, which includes socialist-, post-structuralist/postmodern-, and post-colonial perspectives, characterizes gendering processes and practices as the product of power relations which have emerged from historical processes, dominant discourses, institutions, and epistemological arguments (Calás, Smircich, \& Bourne, 2007). Gender is thereby understood as somewhat distanced from an individual's personal experiences, and is considered to be a linguistically-, historically-, culturally-, and politically constructed process and practice. Such perspectives may be used for a feminist analysis of the relations of power in which gender (and other identities) are seen to produce, reproduce, or resist social systems.

The most common approach in research on women's (and men's) entrepreneurship, however, is an approach which does not problematize gender and power relations (Ahl, 2006; Calás, Smirchic, \& Bourne, 2009), as described above. An example of this approach is the neo-liberal approach identified by Mayoux (2001), which regards women-owned businesses primarily as a means for increased economic growth and national prosperity.

\section{Feminist entrepreneurship policy research}

Feminist research on entrepreneurship policy may, in order to count as feminist proper, ask questions such as Why does a policy support women's entrepreneurship in the first place? (Ahl, 2006; Marlow, 2014), What assumptions are used for making policy initiatives? and How do policies position women? One such study, which compared entrepreneurship policies for women in Sweden and in the USA, showed that policies in both countries assumed a male norm and positioned women as either inadequate and in need of 'fixing', or as being able to make unique ('womanly') contributions. Both countries motivated their support for women's entrepreneurship as a means to meet the ends of economic growth, and not as a means to women's well-being and financial- or other independence (Ahl \& Nelson, 2015; Marlow, Shaw, \& Carter, 2008). Other studies of policy have found that focus is typically placed on measures designed to help women mitigate assumed shortcomings in skills, experience, or attitudes, so they can grow their businesses (Foss, Henry, \& Ahl, 2014; Marlow, 2014).

Similarly, Tillmar (2007) examined a regional support programme for women entrepreneurs in Sweden which viewed entrepreneurship and entrepreneurs as male, and, as a consequence, women's business ownership and entrepreneurship was poorly recognized. Likewise, Berglund \& Granat Thorslund (2012) found Swedish and European entrepreneurship and innovation policies to be constructed in accordance to a male norm; entrepreneurship was imagined to be performed by male businessmen and innovation policy constructed engineers as male. In both cases, women were turned into 'others' in need of 'fixing', in order to be able to compete with the two male benchmarks. However, another Swedish study concluded that when policy initiatives explicitly incorporated a critique of the male norm, this 'opened up' space for women 
from ethnic minorities to enact entrepreneurship in innovative ways (Berglund \& Johansson, 2007).

A 2012 analysis of state support for women's entrepreneurship in the Nordic region concluded that all of the Nordic countries, had a programme or an action plan, or other initiatives, to support women's entrepreneurship, but these programmes varied in their underlying paradigms and rationales (Pettersson, 2012). Norway was placed at one end of a spectrum because its policy programme was most clearly influenced by a so-called 'feminist empowerment paradigm'. At the other end of the spectrum was Denmark, which most clearly focused on economic growth; in line with a neo-liberal paradigm. Between these extremes, we find Sweden, Finland, and Iceland. All of these programmes tended to put women in a subordinate position to men and thereby risked sustaining a male norm in entrepreneurship and in entrepreneurship policy (Pettersson, 2012).

In contrast, Braidford, Stone, and Tesfaye (2013) found a focus on 'poverty reduction' in women's entrepreneurship policy in Canada and the USA. An earlier support programme in Sweden posed the goal of combating long-term unemployment among women (Nilsson, 1997). The argument of 'poverty-alleviation' was also found to be present in a study of UK policy, placing emphasis on the heterogeneity of women, social enterprise, and 'lifestyle' small businesses (Wilson, Whittam, \& Deakins, 2004). Similarly, in Rouse and Kitching's (2006) study of UK policy for the support of business start-ups by women and people from 'disadvantaged' backgrounds, they found arguments for promoting social inclusion by enabling excluded groups to take paid work.

Research on women's entrepreneurship policies from a feminist perspective features quite strongly in the Nordic context (Ahl, Berglund, Pettersson, \& Tillmar, 2016). The feminist perspectives used in extant studies vary, however, and are not always directly comparable with each other. There is a need to develop an encompassing analytical framework in order to facilitate cumulative knowledge building, and to enable new research questions.

\section{Gender (in-)equalities in Scandinavia}

There is a wide-spread image of the Scandinavian countries as being among the most gender equal in the world (for example, UNdata, 2012), and also an image of similarity between Scandinavian countries in this respect. Denmark, Norway, and Sweden are sometimes characterized as 'Scandinavian welfare states' (Sainsbury, 1999), as well as 'women-friendly states' (Hernes, 1987). However, they have also been found to be different from each other. For example, the gender-political model is the most institutionalized model in Sweden, compared to Denmark and Norway (Borchorst, 2011). This implies that there is a strong discourse about women's structural oppression; gender is highly politicized and feminist influences are stronger within political parties than in civil society. Denmark has the least institutionalized model and Norway's model falls in between the others. Furthermore, Sainsbury (2001) found marked differences between Norway and Sweden, because the former has been influenced by deeplyembedded notions of gender difference and a strong 'maternalist' tradition of separate gender- 
roles, with the 'domestic mother' as the norm. Sweden has, instead, been influenced by an equal rights feminist movement, with women's economic independence being realized through paid work resulting in the 'employed mother' as the norm. These differences have, however, diminished over time. Another difference is the Norwegian tradition of gender quotas. Affirmative action has regulated recruitment in Norway for over 30 years across various sectors of society, including education and public sector employment, and, since 2004, corporate boards (Teigen, 2000; 2011).

The use and various interpretations of the concepts 'gender' and 'equality' in the Scandinavian countries' policies, politics, and daily life have been critically scrutinized, and the question of whether these countries are really true champions of gender equality has been raised (Magnusson, Rönnblom, \& Silius 2008; Borchorst \& Siim, 2008; Martinsson 2016; Melby, Carlsson, \& Wetterberg 2009). For example, women in the Scandinavian countries have a high level of labour market participation, but they work on a part-time basis more often than men, and more often than women in countries where full-time employment is the norm. Labour markets are heavily gender-segregated; 74 per cent of public sector employees (including education, care, health care, and defence) are women. The public sector is also the largest employer in the Nordic countries, employing more than 33 per cent of the work force. Women also dominate in the private service sector (67 per cent). Men dominate in sectors such as construction (91 per cent), agriculture (76 per cent) and manufacturing (72 per cent) (Haagensen, 2014). In Denmark, the proportion of self-employed women, as a percentage of the employed, is 3 per cent, and for men 10 per cent. In Norway, the corresponding figures are 3 per cent for women, and 8 per cent for men, and, in Sweden, 4 per cent for women, and 12 per cent for men (OECD, n. d.).

Top management structures are male-dominated, and, consequently, there are differences in women's and men's earnings (Niskanen, 2011; Haagensen, 2014). There is a gender pay gap of around 15 per cent (norden.statbank.dk/inco05, 3-10-16) in these countries. ${ }^{1}$ The Scandinavian countries have comparatively generous parental leave schemes, but the number of days in which parental benefit is payable varies from one country to another. More and more Scandinavian men make use of these leave schemes in connection with childbirth or adoption, but women still use the majority of these benefits, which has a negative effect on their earnings. Another characteristic feature of the Scandinavian countries is the high number of child care options. Appendix A provides a summary of some statistics on gender (in-)equalities in the Scandinavian countries.

\footnotetext{
${ }^{1}$ According to the Nordic statistics (www.norden.org/en/fakta-om-norden-1/numbers-and-statistics, 3-10-16) the unadjusted Gender Pay Gap (GPG): "represents the difference between average gross hourly earnings of male paid employees and of female paid employees as a percentage of average gross hourly earnings of male paid employees. Unadjusted: The indicator is not adjusted according to individual characteristics that may explain part of the earnings difference" (norden.statbank.dk/inco05, 3-10-16).
} 


\section{Method and material}

\section{Discourse analysis}

Discourse analysis as a method of analysis is compatible with post-structuralist feminist analysis, since both build on social constructionist epistemology in which language (or discourse) is seen as constitutive of reality, instead of merely representational. Discourses thus have power implications (Foucault, 1972a); they make thought and action feasible or infeasible, legitimate or illegitimate, and they also order people as well as ideas and objects in relation to each other. The more people draw on a discourse, the more institutionalized it becomes and the more powerful it is. Discourses of gender, for example, create effective power relations.

A discourse analysis often starts with a thematic content analysis (see Winther Jørgensen and Phillips, 2002; Wodak and Meyer, 2009). What differentiates discourse analysis from ordinary content analysisis the way in which the material is interrogated; the analysis focuses not only on what the content is, but also on what it does. The analysis interrogates what is included as well as what is not included, or what is only implied. Data is seen as productive rather than representational. We compared policies for women's entrepreneurship in the Scandinavian countries, to see if they are similar to each other, or not. Such comparisons are powerful, not only for drawing important conclusions, but also for uncovering social phenomena (Ragin, 1989). A phenomenon (for example, a feminist approach) is better understood if it is contrasted to an alternative (Brislin et al., 1973).

Congruent with our purpose, we analysed how the policies argue for women's entrepreneurship as well as how they position women and what assumptions they hold about women and their businesses. In order to assess the degree to which the policies adhere to any particular feminist approach, we also applied the analytical framework which is described below.

\section{Analytical tool}

The analysis of support policies for women's entrepreneurship has taken place from within a variety of frameworks. Some recent work (cf. Braidford, Stone, \& Tesfaye, 2013; Pettersson, 2012; Wilson, Whittam, \& Deakins, 2004) has applied the analytical structure that has been developed by Mayoux (2001) which distinguishes between three distinct paradigms, namely; (i) the neo-liberal market paradigm; (ii) the interventionist, poverty alleviation paradigm; and (iii) the women's empowerment paradigm. We argue that this framework needs to be further developed through the incorporation of a broader continuum of feminist approaches so as to allow for a more detailed, fine-grained analysis of policy support for women entrepreneurs. Such an analysis, using Calás, Smirchic, \& Bourne’s (2009) framework has been made by Clark Muntean \& Banu Ozkazanc-Pan (2016) for social entrepreneurship. Here, we develop the model further and apply it to entrepreneurship policy.

As shown above (Table 1), different feminist approaches contain rather different ways of recognizing and challenging male dominance. These different ways of recognizing and challenging male dominance co-vary with differences in epistemological and ontological 
claims, and result in differences with respect to which particular analytical questions can be properly posed. In the present study, we develop, and employ, a feminist analytical framework based on Calás and Smirchic (1996), and Calás, Smirchic, \& Bourne’s (2007; 2009) outlines of six different feminist theoretical perspectives on organizations. These perspectives enable us to pose a broad range of analytical questions with regard to policies, and allow us to provide a detailed interpretation of the various answers that our questions give rise to. The interpretation that we present, in turn, allows for the recognition of possibly ambivalent and contradictory policy elements, and the identification of 'silences' on potential feminist policy perspectives and features in the policies.

The development of the analytical tool, more concretely, implies that we translate and relate the different feminist approaches, as presented in Table 1. (This is complemented with the neoliberal approach to supporting women's entrepreneurship identified by Mayoux (2001)) into a coherent framework. The analytical framework is presented in Table 2. We first present a number of arguments that are associated with each approach related to women's position in society and to entrepreneurship (Table 2, A). We describe the potential broad goals of each policy (Table 2, B) and we formulate potential ways of achieving the goals of each policy, in line with each approach (Table 2, C). Second, we address the question of how the policies potentially position women. We based our investigation of this issue in terms of how human beings and gender are theorized in the various approaches, which allowed us to discern the various potential positionings of women in the policies (Table 2, D).

We have also included an element of image analysis to our analytical framework which is inspired by Kroon Lundell's (2012) analysis of the imagery of women entrepreneurs in Swedish magazines and newspapers. We analyse how women are positioned visually in the policies. For example, women might be positioned visually as 'everyday' working women; as posing 'smiling objects' in accordance with a feminine aesthetic; and/or as (dis)connected to their entrepreneurial activity (cf. Kroon Lundell, 2012). 
TABLE 2: Analytical tool

\begin{tabular}{|c|c|c|c|c|c|c|c|c|}
\hline & & $\begin{array}{l}\text { Neo-liberal } \\
\text { approach }\end{array}$ & $\begin{array}{l}\text { Liberal } \\
\text { feminist } \\
\text { approach }\end{array}$ & $\begin{array}{l}\text { Radical feminist } \\
\text { approach }\end{array}$ & $\begin{array}{l}\text { Psychoanalytic } \\
\text { feminist } \\
\text { approach }\end{array}$ & $\begin{array}{l}\text { Socialist } \\
\text { feminist } \\
\text { approach }\end{array}$ & \begin{tabular}{|l|} 
Post- \\
structuralist/post- \\
modern feminist \\
approach
\end{tabular} & $\begin{array}{l}\text { Post-colonial } \\
\text { feminist } \\
\text { approach }\end{array}$ \\
\hline $\begin{array}{l}\text { Arguments and } \\
\text { presuppositions. }\end{array}$ & A & $\begin{array}{l}\text { Lack of } \\
\text { economic } \\
\text { development } \\
\text { (growth). }\end{array}$ & $\begin{array}{l}\text { Lack of rights } \\
\text { and } \\
\text { opportunities } \\
\text { for women } \\
\text { entrepreneurs } \\
\text { in society, } \\
\text { organizations } \\
\text { and/or in the } \\
\text { extant support } \\
\text { system. } \\
\text { Barriers and } \\
\text { lack of access } \\
\text { to resources } \\
\text { (financial, } \\
\text { education, } \\
\text { training etc.) } \\
\text { affect women } \\
\text { negatively. }\end{array}$ & $\begin{array}{l}\text { Women are } \\
\text { subordinated in } \\
\text { relation to sex- } \\
\text { segregated } \\
\text { entrepreneurship, } \\
\text { labour market, } \\
\text { and family. } \\
\text { Women are not } \\
\text { successful in } \\
\text { entrepreneurship, } \\
\text { or } \\
\text { entrepreneurial } \\
\text { activities, } \\
\text { because of this } \\
\text { subordination. }\end{array}$ & $\begin{array}{l}\text { Women } \\
\text { entrepreneurs are } \\
\text { negatively } \\
\text { influenced by } \\
\text { patriarchal } \\
\text { ideologies. }\end{array}$ & $\begin{array}{l}\text { Society is } \\
\text { characterized by } \\
\text { relations of } \\
\text { power and } \\
\text { inequalities. } \\
\text { Women and men } \\
\text { are 'doing gender' } \\
\text { and 'doing } \\
\text { entrepreneurship', } \\
\text { which construct, } \\
\text { segregate and } \\
\text { control } \\
\text { hierarchies of } \\
\text { gender, class, } \\
\text { race etc. }\end{array}$ & $\begin{array}{l}\text { A 'politics of } \\
\text { representation' } \\
\text { produces gender. } \\
\text { Women and men's } \\
\text { entrepreneurship, } \\
\text { and } \\
\text { entrepreneurship } \\
\text { policy, construct } \\
\text { gender and } \\
\text { positions women } \\
\text { (and men) } \\
\text { (entrepreneurs). }\end{array}$ & $\begin{array}{l}\text { White, } \\
\text { heterosexual, } \\
\text { middle-class } \\
\text { women (and } \\
\text { men) are } \\
\text { privileged in } \\
\text { society, and } \\
\text { entrepreneurship } \\
\text { policy, 'othering' } \\
\text { women (and } \\
\text { men) who do not } \\
\text { conform to these } \\
\text { norms. }\end{array}$ \\
\hline $\begin{array}{l}\text { Arguments and } \\
\text { presuppositions: } \\
\text { Description of } \\
\text { broad policy } \\
\text { goals }\end{array}$ & B & $\begin{array}{l}\text { Economic } \\
\text { growth. }\end{array}$ & $\begin{array}{l}\text { Social change } \\
\text { for women. }\end{array}$ & $\begin{array}{l}\text { Social change } \\
\text { for women. }\end{array}$ & $\begin{array}{l}\text { Social change } \\
\text { for women. }\end{array}$ & $\begin{array}{l}\text { Gendered change } \\
\text { of society. }\end{array}$ & $\begin{array}{l}\text { Gendered change } \\
\text { of society. }\end{array}$ & $\begin{array}{l}\text { Gendered change } \\
\text { of society. }\end{array}$ \\
\hline $\begin{array}{l}\text { Arguments and } \\
\text { presuppositions: } \\
\text { Potential ways of } \\
\text { reaching the } \\
\text { policy goals. }\end{array}$ & C & $\begin{array}{l}\text { Create economic } \\
\text { development } \\
\text { (growth), } \\
\text { through more } \\
\text { entrepreneurship, } \\
\text { more firms, } \\
\text { growing firms, } \\
\text { increased value } \\
\text { creation } \\
\text { embracing } \\
\text { opportunity. }\end{array}$ & $\begin{array}{l}\text { Instil rights, } \\
\text { equal } \\
\text { opportunities } \\
\text { and remove } \\
\text { barriers for } \\
\text { women. Better } \\
\text { equip women } \\
\text { to overcome } \\
\text { barriers. }\end{array}$ & $\begin{array}{l}\text { Perform } \\
\text { consciousness- } \\
\text { raising, create a } \\
\text { 'women's } \\
\text { entrepreneurial } \\
\text { culture', and } \\
\text { make policy- } \\
\text { makers part of } \\
\text { this. Support } \\
\text { women-centred } \\
\text { initiatives in } \\
\text { order to } \\
\text { eliminate gender } \\
\text { segregation and } \\
\text { subordination. } \\
\text { Support women's } \\
\text { separatist } \\
\text { organizing. }\end{array}$ & $\begin{array}{l}\text { Embrace, utilize, } \\
\text { and support } \\
\text { women's unique } \\
\text { sex-role } \\
\text { socialization and } \\
\text { different traits, } \\
\text { as an advantage } \\
\text { for their } \\
\text { entrepreneurship. }\end{array}$ & $\begin{array}{l}\text { Formulate } \\
\text { polices that } \\
\text { refrain from } \\
\text { legitimizing } \\
\text { hierarchies of } \\
\text { gender, class, and } \\
\text { race through } \\
\text { images, symbols, } \\
\text { and ideologies. } \\
\text { 'Undo' gender. }\end{array}$ & $\begin{array}{l}\text { Avoid reproducing } \\
\text { the discursive and } \\
\text { practical } \\
\text { conditions that } \\
\text { give way to gender } \\
\text { inequalities. }\end{array}$ & $\begin{array}{l}\text { Support women } \\
\text { without } \\
\text { 'othering' } \\
\text { racialised } \\
\text { women and } \\
\text { 'others', and } \\
\text { create benefits } \\
\text { for all. }\end{array}$ \\
\hline $\begin{array}{l}\text { How do policies } \\
\text { position women? } \\
\text { What } \\
\text { assumptions do } \\
\text { policies have } \\
\text { about women } \\
\text { and their } \\
\text { businesses? }\end{array}$ & $\mathrm{D}$ & $\begin{array}{l}\text { Women as } \\
\text { 'untapped } \\
\text { resource' for } \\
\text { economic } \\
\text { growth. Women } \\
\text { are 'lacking' (e.g. } \\
\text { 'entrepreneurial' } \\
\text { abilities, } \\
\text { characteristics, } \\
\text { knowledge) in } \\
\text { comparison to } \\
\text { men, and need } \\
\text { 'fixing'. Women's } \\
\text { businesses are } \\
\text { e.g. too few, too } \\
\text { small, or are } \\
\text { growing too } \\
\text { slowly. }\end{array}$ & $\begin{array}{l}\text { Women } \\
\text { entrepreneurs } \\
\text { lack rights , } \\
\text { opportunities } \\
\text { and access to, } \\
\text { e.g. resources, } \\
\text { and they meet } \\
\text { barriers. } \\
\text { Women in } \\
\text { focus: white, } \\
\text { heterosexual, } \\
\text { and middle- } \\
\text { class. }\end{array}$ & $\begin{array}{l}\text { Women are not } \\
\text { successful in } \\
\text { entrepreneurship, } \\
\text { or } \\
\text { entrepreneurial } \\
\text { activities, } \\
\text { because of } \\
\text { subordination. }\end{array}$ & $\begin{array}{l}\text { Women (and } \\
\text { men) } \\
\text { entrepreneurs are } \\
\text { uniquely } \\
\text { different and } \\
\text { expose different } \\
\text { traits. Women } \\
\text { e.g. have a } \\
\text { feminine 'ethics } \\
\text { of care'. }\end{array}$ & $\begin{array}{l}\text { Focus on gender } \\
\text { as processual and } \\
\text { social } \\
\text { constitution } \\
\text { intersecting with } \\
\text { race, class etc, } \\
\text { and e.g. on how } \\
\text { women } \\
\text { entrepreneurs are } \\
\text { doing or undoing } \\
\text { gender. }\end{array}$ & $\begin{array}{l}\text { Attention to } \\
\text { gender as a } \\
\text { discursive } \\
\text { practice, e.g. } \\
\text { reflecting on } \\
\text { positioning } \\
\text { women in } \\
\text { entrepreneurship } \\
\text { policy. }\end{array}$ & $\begin{array}{l}\text { Focus on } \\
\text { racialised, } \\
\text { classed etc. } \\
\text { 'others' and them } \\
\text { being made } \\
\text { invisible or cast } \\
\text { as 'almost } \\
\text { human' in } \\
\text { entrepreneurship, } \\
\text { and } \\
\text { entrepreneurship } \\
\text { policy. }\end{array}$ \\
\hline
\end{tabular}

Sources: After Calás and Smirchic (1996), Calás, Smirchic, \& Bourne’s (2007; 2009) and Kroon Lundell (2012). 


\section{Material}

The materials that we analysed are national government policy programmes from Denmark, Norway, and Sweden, from 2005-2015. We used publicly-available, written materials (including images), comprising, in total, approximately 30 documents and 25 web pages (see Appendix B). These source materials were complemented by information on more recent policy developments and practices which was garnered via telephone interviews, e-mail and mail communication with eight key informants at ministries and governmental agencies (see Appendix C). Citations from the informants and other sources have been translated by the authors into English, unless explicitly noted to be in English in the original. The application of the analytical framework entailed a close reading of the policy documents, and other data (see below), and the interpretation of specific formulations, silences, ambivalences, and images in accordance with the above framework. The analysis was performed country by country.

\section{Policy analysis- country by country}

\section{Denmark - Short-term action plan focusing economic growth}

In Denmark, we find an Action Plan for Female Entrepreneurs (Danish Business Authority, 2009). A background report to the plan noted that women were under-represented among entrepreneurs and even more so among emerging entrepreneurs. Consequently, women were characterised as comprising an 'untapped potential' (Danish Business Authority, 2008). The foreword to the Action Plan elaborated on this, stating: "There is a large potential in getting more women to start firms and to think in growth terms" (Danish Business Authority, 2009:22). The policy rationale, whereby women are considered to be an untapped growth resource, is congruent with a neo-liberal approach.

In the Action Plan, women are shown to start (i) fewer businesses and (ii) businesses that do not grow, and are thus presented as inferior to men. The Action Plan explains the differences between women and men's entrepreneurship by virtue of differences in education and experience in pursuing a business. The Action Plan, somewhat ambivalently, claims that women do not encounter any problems in the existing support system, since they use it to a greater extent than men, but there is still need for an Action Plan. Likewise, the document claims that women are more competent than men: "women have the qualifications and knowledge to be able to start successful and knowledge-intensive businesses, as more women today obtain higher education than men” (Danish Business Authority, 2009:2). But the Action Plan still concludes that women lack competence, growth ambitions, and desire, and, therefore, they need improvement: “The primary focus in the Action Plan is thus to improve women's competence and desire for starting growth oriented businesses” (Danish Business Authority, 2009:2). Women are positioned as inadequate, in comparison to a (silent) male norm, since they are constructed as 'in need of improvement'. The responsibility for change is put on individual women, for the reason of economic growth, which seems decidedly neo-liberal. 
The Action Plan includes seven initiatives for women entrepreneurs. These are: (i) establishing a website with information on women: "which can create growth in their businesses" (Danish Business Authority, 2009:6); (ii) creating an overview of women networks and mentoring; (iii) arranging development courses for women; (iv) making more women students interested in entrepreneurship; (v) developing analyses of alternative growth paths; (vi) making women entrepreneurs more visible as role-models; and (vii) generating yearly statistics on women and men entrepreneurs.

In summary, the seven initiatives tend to position women as being inadequate with regards to getting information, creating their own networks, being leaders, and finding role-models. Women are thereby assumed to lack the abilities of, e.g., getting information and being leaders themselves, and in need of 'fixing', through individual change. The initiatives in the Action Plan do not include any feminist visions of change, or of a 'good and gender equal society'. By applying a feminist approach (for example, a socialist- or liberal feminist approach), the Action Plan could have potentially reflected upon the barriers that women entrepreneurs are confronted with in a gender-segregated labour market, or considered whether the existing business support systems had discriminated against them, for example. However, it is silent on such reflections.

One of two Danish statistical reports covering 2010 and 2011 (www.erhvervsstyrelsen.dk, 0202-16) includes an image of a young white woman wearing a vest, a short skirt and high heels, jumping into the air with her legs open, whilst holding an open laptop. The image is stereotypical - it celebrates femininity, youth, and beauty - rather than work and entrepreneurship. The ample bare skin and the position of the woman's legs in the image tend to sexualize and objectify women. The image reoccurs in an article on women entrepreneurs and the Danish Business Authority (www.busiess.dk, 10-11-18).

A regional authority, Business Development Centre - Southern Denmark, led most of the implementation work for the Danish Business Authority. They named the project Women Can (Godthaab \& Kjær, 2013) which may be interpreted as an exhortation or a 'vision'. The name tends to position women as those who cannot (create growth-oriented businesses) without special help. The Business Development Centre developed a website that included role-models, delivered eight development courses, and published an e-book. The Danish policy implementation could potentially have been used for feminist, women-only organizing, e.g., during the Women Can courses, using a radical feminist approach. But, it does not seem to have been used in such a way. The Business Development Centre also arranged Women Can conferences, where, at one of the conferences, an invited sociologist talked about the so-called 'erotic capital' that women entrepreneurs can use to their benefit. ${ }^{2}$ Talking about women's 'erotic capital' positions women as being entirely different from men; a move which might be interpreted as a radical feminist approach. However, this approach also tends to sexualize and

\footnotetext{
2 This is mentioned in an article in the newspaper FyensStiftstidende (2010-11-18), which is reproduced in Godthaab and Kjær (2013).
} 
objectify women, thus subordinating them in relation to men entrepreneurs, and in society at large.

The Danish Action Plan was completed in 2014. According to the Danish Business Authority, there is currently no need for a specific policy for women entrepreneurs. They state that: "we have no specific Danish policy for women entrepreneurs, because we think that there is no need for one" (e-mail communication, Danish Business Authority, 19-02-14). The only activity that was said to be left is the publication of gender-specific statistics for entrepreneurship. However, such statistics exist for 2010 and 2011 only (www.erhvervsstyrelsen.dk, 02-02-16).

In conclusion, we find that, for the most part, the Danish Action Plan can be seen to be grounded in a neo-liberal approach, as the argument for supporting women is purely focused on economic growth. The plan positions women as deficient individuals, who are in need of improvement. Women are assumed to lack the desire to start businesses, in particular 'growth-businesses'. There are no feminist visions of change in the plan nor is there reference to a 'good society'. The Action Plan came to an end in 2014, and currently there is no Danish policy in place to support women's entrepreneurship.

\section{Norway: Shifting focus from special projects to equal access}

In Norway, the action plan More Entrepreneurship among Women was implemented between 2008 and 2013. The goal of the Norwegian government was: "to prioritize entrepreneurship among women. Our goal is that more women shall become entrepreneurs, and that the share of women among new entrepreneurs is at least 40 per cent before 2013” (Ministries, 2008:5).

In the introduction to the action plan, we note that the rationale behind the Norwegian action plan can be understood as ambivalently mixing the differing approaches of neo-liberalism (focused on women as an underused resource in producing economic growth and welfare) and of a liberal-, or other, feminist approach:

The government will prioritize the work to promote entrepreneurship among women in the whole country and, through this, create a more equal and diverse industry. The point of departure is that a higher share of women entrepreneurs will contribute to more wealth creation, greater flexibility, more innovation and greater adaptability in economy (Ministries, 2008:5).

The action plan involved seven ministries and includes 12 action points: (i) the right to 100 per cent compensation for entrepreneurs who take parental leave; (ii) new support for growth entrepreneurs in the regions; (iii) reinforced focus on women entrepreneurs in the support 
system, through common instructions to governmental agencies, including Siva ${ }^{3}$, Innovation Norway, and the Norwegian Research Council; (iv, v, vi, vii) the strengthening of womenfocused initiatives in the above-mentioned agencies, including women as recipients of support and loans, through role-models, mentoring, networking, increased competence in women, making information visible to women, etc.; (viii) focus on women in regional development, as participants in actions and as recipients of support; (ix) mentoring for young persons; (x) strengthening the role of municipalities in supporting entrepreneurs; (xi) focus on getting more men to take more than the so-called 'father's ratio' of parental leave; and (xii) new research on entrepreneurship and women entrepreneurs.

The action plan described above, to some extent, positions women as inadequate in terms of their competence and networks, which seems neo-liberal. But it also positions women as being caught up in a system where conditions are not right for women:

Independent self-employed persons today do not have the same rights to parental leave support as do the employed. This can make it difficult for self-employed persons to combine care and work activities and share the responsibility between parents (Ministries, 2008:6).

The positioning suggested in the extract above primarily follows a liberal feminist approach, which is centred on individual women's lack of rights and access to resources. The initiative which seeks to get more men to take parental leave in order to support women entrepreneurs could be interpreted as radical feminist, as it concerns women's subordination within the family. Again, we observe an ambivalence between a neo-liberal- and a liberal feminist approach, but also appeals to a radical feminist approach.

The action points that were initiated in the action plan have continued after 2013, according to the responsible ministry, because: "it is not a time-limited action plan. The efforts still apply." (telephone interview, Ministry of Local Government and Modernization, 26-02-14). This statement complements that which was written in a 2013 whitepaper, where the government affirmed that: "the women-focused work will be continued, as an integrated part of all actions" (Parliament notification, 2013:97).

Post 2013, however, we note that fewer and fewer of the action points mentioned above are actually being implemented. The grant support (ii) and the research programme (xii) are completed. As for action point (xi), to get more men to take more parental leave, no conclusions about the significance of this effort can be drawn, according to the Ministry of Children, Equality, and Social Inclusion, since the size of the father-quota has varied over time (mail

\footnotetext{
${ }^{3}$ Siva is a public enterprise owned by the Norwegian Ministry of Trade and Fisheries. It a public funding agency for innovation and works closely with Innovation Norway, the Norwegian Research Council, and the Norwegian Patent Office (siva.no/om-oss/?lang=en, 03-05-16).
} 
communication, Ministry of Children, Equality, and Social Inclusion, 14-05-14). Consequently, the connection of this action point to women's entrepreneurship seems lost. The status of some of the other action points is unclear (namely, actions (i), (iv), (viii), and (x)). The special action points for women in (v, vii and ix) have been completed by the responsible agencies, namely Sivan and Innovation Norway, and they are now engaged in increasing the share of women in all activities instead (e-mail communication, Innovation Norway, 29-04-14; telephone interview, Ministry of Local Government and Modernisation, 26-02-14), thereby primarily following a liberal feminist approach which is focused on equal access to resources.

Earlier special action points for women included Siva's Woinnovation, a 'woman innovation programme', 2006-2013, which was described as an effort to offer women networks, competence, and inspiration. This offer seemed to be built on a neo-liberal approach, where women were compared to men, and positioned as entrepreneurs who lacked competence, and were thus in need of fixing. As stated by Siva:

Women start businesses less often, and they start other types of businesses, than men. It is most often one-person-businesses with low risk, low growth ambitions, directed to a local market. Moreover, women have a much higher threshold when it comes to starting their own businesses compared to men (kvinnovasjon.no, 0605-14).

Since Woinnovation was said to give women equal access to networks and competencies (kvinnovasjon.no, 06-05-14), a liberal feminist approach can also be detected in this project. Parallel to the work that has been performed by Siva, Innovation Norway has, since 2009, sought to integrate a so-called 'women-perspective' in all of their actions through a strategy which builds upon a neo-liberal approach, as focus is placed on women as contributors to economic growth:

The overarching goal in this strategy has been to contribute to increased valuecreation through strengthening women's participation and position in the industry as founders, as leaders, and on boards” (e-mail communication, Innovation Norway, 29-04-14).

A radical feminist approach is also observed in the formulation of the aim of strengthening women's industrial positions, which are then viewed as subordinate.

Thus, the only two efforts that are still in place from the original action plan, concern the instructions to the governmental agencies the Norwegian Research Council, Innovation Norway and Siva. The three governmental agencies are supposed to distribute an equal share of their funding between women and men entrepreneurs. A liberal feminist approach is prominent in these actions since they concern equal access. However, the instructions given to the Norwegian Research Council in 2014 does not focus on women (Ministry of Local Government and Modernisation, 2014a). But, in 2015, the Research Council was informed that: "women is a prioritized group, and there is a goal of at least 40 per cent of the industrial support under the 
ministry should reach women” (Ministry of Local Government and Modernisation, 2014b:2). In 2016, this quantitative goal was not achieved (again).

Innovation Norway and Siva have sought to distribute an equal share of their funding between women and men entrepreneurs in a gender quota-like fashion, since the government's instruction to Siva for 2014 (and 2015) stated: “40 per cent of the industrial support, under the Ministry, shall reach women (Ministry of Local government and Modernization, 2013d, p. 2; 2015b). In a similar way, the instruction to Innovation Norway, for 2014, stated: "Women, the young (18-35 years), and immigrants are prioritized groups. At least 40 per cent of the industrial support under the ministry shall reach women" (Ministry of Local government and Modernization, 2013b, p. 2; 2015a).

However, in 2016, Innovation Norway and Siva were informed that: "this Ministry puts an emphasis on projects being evaluated regarding their quality. Within these frames the goal is that at least 40 per cent of the industrial support funding shall reach women" (Ministry of Local Government and Modernisation, 2016b:2; 2016c:2). Focus is thereby shifted from an equal share of funding between women and men, to 'quality' in funded projects. This indirectly positions women as less capable of proposing quality projects. The 'quality-argument' can be interpreted as a form of 'competence-argument', which is often presented in debates on gender quotas. It constitutes a non-feminist resistance against a liberal feminist approach which is focused on equal access to resources. 'Competence' is set in opposition to gender equality (cf. Tienari, Holgersson, Meriläinen, \& Höök, 2009), and it is feared that less competent women will replace more competent men through the use of quotas (cf. Storvik \& Teigen, 2010). This shift in the Norwegian approach to this matter balances across a thin line between a liberal feminist and a neo-liberal approach with respect to women's entrepreneurship policy.

The action plan comprises a background part, a part that presents the 12 action points, and a part that presents four women entrepreneurs and their businesses. The imagery that appears in the action plan includes happy, smiling women entrepreneurs, sometimes doing 'unusual' things. The images feature a woman surrounded by goats; a woman wearing red wellington boots, walking on a beach; and a woman jumping with her legs folded to one side and her arms stretched above her head in the shape of a large ' $\mathrm{V}$ ', presumably celebrating her entrepreneurial victory. In yet another image, we see a woman holding an open laptop computer over her head. All of the pictures were photographed in outdoor settings. These full-page images of women entrepreneurs stand in stark contrast to the small images of the seven government ministers, all of which are contained by half a page. The ministers were photographed in a studio, and the images show the ministers' (sometimes smiling) faces, not their whole bodies. The imagery of the four women entrepreneurs position women as very happy, nice-looking, and as not so serious. Since they are not represented as being busy 'doing their business' (except for the goat farmer) the impression of flippancy is somewhat amplified. The women are positioned as 'improper' entrepreneurs, reduced from serious entrepreneurs to smiling, non-serious 'girls' who are merely playing at being entrepreneurs (cf. Kroon Lundell, 2012). 
With respect to the Norwegian action plan and consequent work, we conclude that the plan changed from (A) employing a wide range of initiatives (which were grounded in neo-liberal and liberal feminist perspectives, including a potentially radical feminist approach which focused on men's role in the family in relation to women's entrepreneurship) to (B) a narrower range of initiatives that were merely aimed at promoting equal access to funding. Note that even the latter initiative has changed focus recently since it now evaluates the 'quality' of entrepreneurial projects, which tends to position women as less capable, and is not only concerned with the provision of equal access to funding for men and women. This gradually less ambitious (from a feminist perspective) Norwegian support for women entrepreneurs thereby seems to abandon the liberal feminist approach altogether for the benefit of a neo-liberal approach which is focused solely on economic growth.

\section{Sweden: From national promotion programmes to programmes for equal opportunities}

Since the 1990s, Sweden has seen the implementation of several government efforts with the intention of supporting women's entrepreneurship, including two national programmes to promote women's entrepreneurship that were launched in 2007-2010 and in 2011-2014. The government's decision with respect to the 2007 programme included the following remarks:

Considerably fewer women than men pursue businesses in Sweden and the share of women entrepreneurs on the labour market is also low compared to other European countries. More women pursuing businesses would imply that more business ideas are utilised and that Sweden's possibilities to get an increased number of employment opportunities, and economic development, would be enhanced. [...] women's opportunities to start and pursue businesses shall be improved and obstacles that obstruct women's entrepreneurship shall be removed (The Government, 2007:3).

The 2011 programme (The Government, 2011) repeats this formulation, except for the last sentence, which is omitted. Therefore, we note a slight shift in the approach that is adopted in the first programme when we compare it to the second programme. The first formulation combined a neo-liberal approach, with focus on the nation's economic development, articulating a liberal feminist approach which aimed at providing equal opportunities. The second formulation tends to feature the neo-liberal approach only. (Both programmes, however, feature a variety of feminist approaches, as we will show below).

The proposed 'remedies' in both programmes focus on individual women, through regional business and innovation development programmes, and by making certain women entrepreneurs visible as 'ambassadors' for women entrepreneurs. The Swedish Agency for Economic and Regional Growth reports that a great number of women have participated in these initiatives. For example, 477 business and innovation development efforts were funded between 2011 and 2014. They report that: "women pursuing businesses or aspiring to start businesses, for example, received coaching, advisory guidance, and access to networks, in order 
to develop their businesses or their ideas" (www.tillvaxtverket.se, 03-03-16a). The designation of entrepreneurship ambassadors included 2000 women as ambassadors, who met with almost 170000 people between 2008 and 2014 (www.tillvaxtverket.se, 03-03-16b). These efforts tend to position women as if they were unable to develop their ideas or businesses or act as rolemodels (or find role models) on their own. These observations resonate with the neo-liberal approach inherent in this policy. Furthermore, these efforts do not include any feminist visions of change, or of a 'good society'.

The fact that the ambassadors were expected to deliver their services for free also seems somewhat paradoxical, when we know that 'time is money' for any entrepreneur. The fact that the ambassadors were tasked to target their efforts at school pupils, NGOs, networks, and individual women further reinforces the interpretation that a neo-liberal approach was at play. A feminist approach would have promoted the idea that the ambassadors might tell their stories to the business world in general, or perhaps, even better, to business promoters within the ordinary business promotion system, who may have an inadequate understanding of the gendermarked opportunities for women in business, and their attendant unequal access to support. In practice, the efforts with respect to business and innovation development, and the ambassador action, could (also) have been used for separate feminist, women-only organizing, during courses or meetings, following a radical feminist approach.

The neo-liberal approach that is present in the Swedish women entrepreneur promotion programmes is somewhat ambivalently 'balanced' by the programme effort of diffusing knowledge of women's entrepreneurship into the existing support system, since it aims to: "improve the quality of advisory services for women who are, or want to become, business owners" (The Government, 2011:5). The latter can be interpreted as featuring a socialist feminist approach, focusing on the inequalities within the support system and with anticipated changes in this system, and not with respect to individual women.

Another feature of the 2011-2014 programme was a training course, Take the lead!, that was addressed towards municipal politicians and business support counsellors. This training course was aimed at increasing knowledge of how to promote business for women and men on equal terms. This course also included an element of 'gender mainstreaming' which was intended to transform the support system by questioning the gendering of the concept of 'entrepreneur' and by questioning the claim that women are a homogenous minority group, for example (The Swedish Agency for Economic and Regional Growth, 2015a). This reveals a post-structuralist approach in terms of how the constructions of gender in the support system were problematized and how a 'deconstruction' of these concepts might take place. Seven pilot projects that were aimed at integrating gender aspects of business promotion were also performed during this time (The Swedish Agency for Economic and Regional Growth, 2015b). This effort could be interpreted as including a liberal feminist approach that promoted equal access. 
One action in the 2011-2014 programme included the development of a new strategy for establishing equal conditions within the existing support system. This strategy was called Open $U p$ ! and contained the following aim:

The strategy's purpose is to contribute to the development of the publicly funded business promotion at the national, regional and local levels in order to achieve the long-term goal - that women and men, regardless of ethnic background or age, should be able to avail themselves of business promotion resources under equivalent conditions (The Swedish Agency for Economic and Regional Growth, 2015c:11).

The purpose of the strategy centred on equal access to support resources (financial, advisory, regulatory, etc.), thereby clearly indicating a liberal feminist approach. However, we also note the goals of: "economic renewal and sustainable growth" (The Swedish Agency for Economic and Regional Growth, 2015d:3, English language in the original), indicating that the strategy is actually grounded in a neo-liberal approach. The perceived challenges in the business promotion system, however, also included a discussion of the masculine norm in entrepreneurship. The strategy is thus also influenced by a post-structuralist approach, since it questions the efficacy of the existing support (actors). With respect to Open Up!, eight goals for change are stated, but we note that the changes that are anticipated by the programme are not changes with respect to women, but, instead, they are changes in the support system. This could also be interpreted as an articulation of a socialist feminist approach, in terms of asking how support policies are 'doing gender', and how policies can refrain from legitimizing gender, race-, and class hierarchies, through the deployment of specific images, symbols, and ideologies.

The imagery that is employed in presenting the strategy includes a range of pictures: a rainbow, plants, a sound system with a pair of hands, a number of pairs of shoes forming an arrow, and a compilation of disparate objects, including a law book and a yoga mat (The Swedish Agency for Economic and Regional Growth, 2015d). Notably, it also contains photographs of people who are not often associated with entrepreneurship, something which can be interpreted as a post-colonial approach. The photographs include a 'white' man (in the spotlight) and a 'coloured' woman (in the shadow) with the following accompanying text: "How do we reach everyone?" However, we note that the spotlight is on the man and the woman is in the shadow. There is also a collage with men and women, including people of colour and of various ethnic origins, with the text: “The vision is a diversity of businesses and entrepreneurs”. This imagery can be interpreted as echoing a post-colonial approach, and the strategy document also states that the existing support system lacks knowledge about the importance of gender, ethnicity, age, gender equality, and diversity. No explicit discussion of race or racism is found in the text.

The Swedish promotion of women's entrepreneurship has recently come to an end. These programmes have included a potential liberal feminist approach and (possibly) a poststructuralist approach. However, a neo-liberal approach permeates these plans since they position women as individuals who are in need of development efforts, whilst the overarching 
goal is economic growth. The new phase of support for women entrepreneurs includes the strategy entitled Open Up! The title of this strategy suggests that a more equal distribution of support resources will be provided. However, no agency has been given the responsibility to implement the strategy, so what will result, if anything, is uncertain.

\section{Results and discussion}

This paper has presented an analysis of feminist approaches taken in policies for women's entrepreneurship in the Scandinavian countries. We analysed how the policies argued for women's entrepreneurship, as well as how they positioned women and what assumptions they held about women and their businesses. We developed and applied an analytical tool that is based on established feminist theoretical frameworks. We found variance in the feminist approaches taken in the policies for women's entrepreneurship across the Scandinavian countries. In spite of studying a relatively short time period, we found that the feminist approaches varied within each respective country over time.

bThe analytical framework developed in this paper has helped us recognize that, even though the Scandinavian policies for women entrepreneurs claim to target women, there was, towards the end of the period studied, a 'silencing' on feminist approaches. The analysed polices have thus, on an overarching level, gone from including a broad range of feminist approaches to a more straight-forward application of a neo-liberal approach, with no feminist ambitions apparent. In addition to this, the extent of the support for women's entrepreneurship in the Scandinavian countries became more limited over the time period that was studied: The Danish action plan was completed in 2014. The Norwegian action plan has become more and more limited, as fewer and fewer actions are performed, and the Swedish programmes to promote women's entrepreneurship are completed, and, at present, only a strategy with unclear ‘ownership' remains.

From a wider perspective, we note that there is a lack of suggestions about what a 'good society' (in terms of gender equality), might be constituted of, other than the production of economic growth. The policy efforts do not contain any clear formulations of feminist goals, in terms of either social change for women, such as entrepreneurship as a means to women's well-being and financial or other independence, or in terms of gendered change of society, such as changing the (male) entrepreneurial norm or challenging gendered social hierarchies. Consequently, the policies do not seek to improve women's standing in society relative to men. Instead, they implicitly support the status quo. Furthermore, we interpret some of the policies (or policy actions/efforts) as an impediment for improving the situation for women, because they position women as ‘inadequate' and 'unable’ to, for example, develop their ideas or businesses.

The lack of goals with respect to a gender-equal society is especially true in the case of Denmark. The action plan in Denmark, which was a one-off policy measure directed towards women entrepreneurs, was strongly grounded in a neo-liberal approach. The only argument in favour of supporting women entrepreneurs was that women are a resource for economic growth. 
The economic growth argument in favour of providing support for women entrepreneurs is also clearly present in the Norwegian and Swedish policies. However, it is complemented with other arguments, at least in the beginning phase of the Norwegian action plan. This move is actually more apparent during the whole period in the Swedish context. In the case of Norway, the focus on the neo-liberal approach tends to be mixed with feminist approaches, as an argument for the creation of a more gender equal industry is underlined, at least when the action plan was first presented. A liberal feminist approach, centred on individual women's lack of rights and access to resources, is most prominent in the Norwegian policy, through the inclusion of quota-like measures for the distribution of funds (see Teigen, 2000). However, the recent shift in the remaining support for women entrepreneurs indicates an end to the liberal feminist approach, and use of quotas. Focus is solely placed on economic growth, which is congruent with a neoliberal approach.

The Swedish promotion programmes for women entrepreneurs were also grounded in a neoliberal approach, even though liberal-, socialist-, and post-structuralist feminist approaches also featured in these programmes. The arguments that were put forward in the programmes were formulated in terms of (i) enhancing economic development, (ii) making use of more business ideas, and (iii) improving women's opportunities to pursue a business. Even if strands of socialist or post-structuralist approaches do feature in the Swedish policy, the latest policy - a strategy for establishing equal conditions within the existing support system - applies a liberal feminist approach. The strategy argues for economic and sustainable growth and states everyone should have equal access to business promotion resources.

The overall Scandinavian tendency to focus policy on economic growth is further demonstrated by the fact that, in Denmark and Sweden, the relevant governmental agencies for executing the policies for women's entrepreneurship are agencies tasked with business development and economic growth (the Danish Business Authority and the Swedish Agency for Economic and Regional Growth, respectively). In Norway, however, seven different ministries were involved in the policy implementation, whilst the policy work itself was led by the Ministry of Local Government and Modernization. This broader scope of actors has, however, been narrowed down over time. At present, only two governmental agencies that are focused on business development are involved in performing the remaining actions.

It should, however, be noted that there have been potential openings for the use of various feminist approaches in the analysed policies, because a certain ambivalence with respect to the approaches exists. For example, the Danish Women Can courses and the Swedish entrepreneurship ambassadors could potentially have been used for separate radical feminist organizational efforts. They could offer a space for women to formulate and act on what is problematic for them in terms of gendered inequalities. If this actually happened in practice remains to be subject to future research. The Swedish strategy also allows for post-structuralist and post-colonial feminist approaches, but if and how such approaches will be implemented, are also questions for future research. 
In summary, our main conclusion is that economic growth is put to the fore, in line with a neoliberal approach, as the overarching goal in policies for women's entrepreneurship in all of the Scandinavian countries. We therefore conclude that, despite claiming to support women, the actual aim of the policies for women entrepreneurs often seems to be economic growth, and women are seen merely as an untapped, but yet not fully 'adequate', resource.

This paper did not investigate gender equality per se. Notwithstanding this, the policy analysis presented in this paper challenges the image of the Scandinavian countries as being genderequal. Scandinavian policies for women's entrepreneurship not only privilege economic growth, but also do so to greater degrees over time. The policies contain little or no reasoning with respect to gender inequalities, neither in terms of social change for women, nor in terms of gendered change of society (see Calás, Smirchic, \& Bourne 2007; 2009). Based on the silencing of feminist approaches in these policies on women's entrepreneurship, we conclude that none of the countries referred to in this paper fully live up to their image as gender equal.

Our analysis reveals that there is a certain degree of similarity between the Scandinavian countries in the sense that their policies are all fundamentally informed by a neo-liberal approach which aims for economic growth. Notwithstanding this observation, differences can be found across these nations. As mentioned above, Denmark's action plan was strongly grounded in a neo-liberal approach aiming for economic growth, with little or no feminist ambitions. This might be interpreted as mirroring the least institutionalized gender-political model among the Scandinavian countries (see Borchorst, 2011). Meanwhile, Sweden and Norway more strongly feature a liberal feminist approach through a silencing of other feminist approaches, especially in Norway. This could be interpreted as Norway and Sweden becoming more alike during the studied time period. In the current Norwegian policy, there are a few traces of the Norwegian maternalist tradition (see Sainsbury, 2001). One striking difference between Norway and Sweden has, however, been the Norwegian implementation of genderquota ambitions in setting quantitative goals for the distribution of funding for entrepreneurs (see Teigen 2000; 2011), while such a move has not been made in the Swedish programmes. However, since gender quotas have disappeared in the latest actions following the Norwegian support policy, the countries have become more alike.

We also find that the number of similarities between the three countries actually seems to increase over time. However, these similarities do not concern gender equality, but rather, a similar tendency to neglect gender equality. We claim this because the extent of the support for women's entrepreneurship in the Scandinavian countries has become more limited over time and more focused on economic growth.

We believe that the turn away from feminist goals and approaches and the gradually stronger emphasis on a neo-liberal approach that is apparent in the studied policies can be interpreted as being influenced by a larger societal discursive change where entrepreneurs and entrepreneurship have become increasingly more popular. Entrepreneurship is seen as the engine of economic growth (Birch 1979), alleviating pressing problems of unemployment. This 
discourse has been used to argue for measures that are aimed at increasing gender equality on business terms (the so called 'business case for gender equality' (see Herring, 2009), which is clearly evident in our analysis. However, as demonstrated in this paper, this entails a weakening and undermining of the feminist agenda.

Perhaps the extent of the popularity of entrepreneurship and view of the entrepreneur as a kind of saviour of the economy leaves little room for any other way of viewing entrepreneurship. The connection between, on the one hand, entrepreneurs and entrepreneurship and, on the other hand, economic growth thereby seems somewhat inevitable, in the light of this prevailing discourse. This connection is thus often evident, even though some entrepreneurship research has argued for other understandings of entrepreneurship, for example, as social change (see Calás, Smirchic, \& Bourne 2007; 2009) and as including feminist change (Ahl et al., 2016). Entrepreneurship policy has also been shown to not only be focused on economic growth. For example, entrepreneurship policy has been found to focus on goals of poverty reduction (Braidford, Stone, \& Tesfaye, 2013; Wilson, Whittam, \& Deakins, 2004), and social inclusion (Rouse \& Kitching, 2006), thereby arguing that entrepreneurship can be disconnected from 'pure' economic growth.

The analytical tool that was presented in this paper proved to be productive. We suggest that it can guide future research on policy for supporting women's entrepreneurship, or policy initiatives that are focused on women or gender, in Scandinavia or elsewhere, at national or other geographic levels. We also suggest that the analytical tool can be applied in studies of policy implementation and effects in various contexts, including Scandinavia. Future policy implementation processes in the area of support for entrepreneurship remain important areas for feminist research. Further research could focus on what regional policy actors and women have done with policy actions in practice. Have they used them in accordance with a particular feminist approach, or not? and, in cases where particular feminist approaches are employed: Which approaches were employed and how? Another area of research could include the investigation of any 'feminist resistance' that might be produced by putting policy into practice (see Pettersson \& Lindberg, 2013).

The analytical framework that is presented in this paper should be instructive, not only for academics who might wish to study other national contexts, but also for politicians and policy makers as they develop and discuss various rationales for the support of women entrepreneurs. In a reflective way, the analytical framework makes it possible to ask what diagnosis and remedy a specific policy might seek to make by providing the policy-maker the opportunity to choose from a broad range of feminist approaches. Not unrelated to this, we note that it is also important to choose the imagery that is included in policy documents wisely.

\section{Conclusions}

Our main conclusion is that even if a liberal feminist perspective is present in policies for women's entrepreneurship, along with elements of radical- and post-structuralist feminism, Scandinavian polices often give precedence to economic growth in a neo-liberal fashion, and 
position women as a means to an end. Over time, economic growth becomes the key focus, while feminist approaches are silenced. The polices thus tend to argue for the support of women's entrepreneurship because they are seen as constituting a resource for economic growth. Given the presence of this focus on economic growth, another conclusion that we draw in this study is that women entrepreneurs are often positioned as inadequate, in comparison to a male norm. Women could, by starting growing businesses, contribute to economic growth if only they were 'fixed' in some way. Our analysis reveals that there exists a certain degree of similarity between the Scandinavian countries in the sense that their policies are all fundamentally informed by a neo-liberal approach which aims for economic growth. Notwithstanding this observation, significant differences can be found across these nations.

\section{Acknowledgements}

We want to thank the anonymous reviewers for their helpful comments. This research was funded by the Swedish Research Council

\section{References}

Acs, Z. J., \& Szerb, L. (2007). Entrepreneurship, economic growth and public policy. Small Business Economics, 28, 109-122.

Ahl, H. (2006). Why research on women entrepreneurs needs new directions. Entrepreneurship Theory and Practice, 30, 595-621.

Ahl, H., Berglund, K., Pettersson, K., \& Tillmar, M. (2016). From feminism to FemInc.ism: On the uneasy relationship between feminism, entrepreneurship, and the Nordic welfare state. International Entrepreneurship and Management Journal, 12, 369-392.

Ahl, H., \& Marlow, S. (2012). Exploring the dynamics of gender, feminism and entrepreneurship: advancing debate to escape a dead end? Organization, 19, 543-562.

Ahl, H., \& Nelson, T. (2015). How policy positions women entrepreneurs: A comparative analysis of state discourse in Sweden and the United States. Journal of Business Venturing, 30, 273-291.

Audretsch, D. B., Grilo, I., \& Thurik, A. R. (2007). Handbook of research on entrepreneurship policy: Edward Elgar Publishing.

Berglund, K., \& Granat Thorslund, J. (2012). Innovative polices? Entrepreneurship and innovation policy from a gender prspective. In Andersson, S., Berglund, K., Gunnarsson, E., Sundin, E. (Eds.) Promoting Innovation - Policies, Practices and Procedures, VINONVA REPORT VR 2012:8. Stockholm: VINNOVA.

Berglund, K., \& Johansson, A. W. (2007). Entrepreneurship, discourses and conscientization in processes of regional development. Entrepreneurship and Regional Development, 19(6), 499525.

Birch, D. (1979). The Job Generation Process. Cambridge, MA: MIT Press.

Borchorst, A. 2011, Scandinavian Gender Equality: Competing Discourses and Paradoxes. In Addis, E., de Villota, P., Degavre, F., \& Eriksen, J (Eds.). Gender and Well-being: The Role of Institutions, (pp. 63-76). London: Routledge.

Braidford, P., Stone, I., \& Tesfaye, B. (2013). Gender, disadvantage and enterprise support - lessons from women's business centers in North America and Europe. Journal of Small Business and Enterprise Development, 20, 143-164. 
Bruni, A., Gherardi, S., \& Poggio, B. (2004a). Entrepreneur-mentality, gender and the study of women entrepreneurs. Organizational Change Management, 17, 256-268.

Bruni, A., Gherardi, S., \& Poggio, B. (2004b). Doing gender, doing entrepreneurship: an ethnographic account of intertwined practices. Gender, work and organization, 11, 406-429.

Brush, C. G. (1992). Research on women business owners: past trends, a new perspective and future directions. Entrepreneurship, Theory and Practice, 16, 5-30.

Calás, M. B., \& Smircich, L. (1996). From "The Woman's" Point of View: Feminist Approaches to Organization Studies. In S. Clegg, C. Hardy \& W. Nord (Eds.), Handbook of Organization Studies (pp. 218-257). London: Sage.

Calás, M. B., Smircich, L., \& Bourne, K. A. (2007). Knowing Lisa? Feminist analyses of «gender and entrepreneurship». In D. Bilimoria \& S. K. Piderit (Eds.), Handbook on women in business and management (pp. 78-105).

Calás, M. B., Smircich, L., \& Bourne, K. A. (2009). Extending the Boundaries: Reframing "Entrepreneurship as Social Change" Through Feminist Perspectives. The Academy of Management Review 34, 552-569.

Coleman, S. (2000). Access to capital and terms of credit: a comparison of men- and women-owned small businesses. Journal of Small Business Management, 38, 37-52.

Davidsson, P., \& Wiklund, J. (2001). Levels of analysis in entrepreneurship research: Current research practice and suggestions for the future. Entrepreneurship Theory and Practice, 25, 81-100.

DuRietz, A., \& Henrekson, M. (2000). Testing the female underperformance hypothesis. Small Business Economics, 14, 1-10.

European Commission. (2013). Communication from the commission to the European parliament, the council, the European economic and social committee and the committee of the regions Entrepreneurship 2020 action plan, Reigniting the entrepreneurial spirit in Europe. Brussels: EU

Fabowale, L., Orser, B., \& Riding, A. (1995). Gender, structural factors, and credit terms between Canadian small businesses and financial institutions. Entrepreneurship, Theory and Practice, 19, 41-65.

Foss, L., Henry, C., \& Ahl, H. (2014). Review of Policy and Practice Implications in Gender and Entrepreneurship Research. In Diana International Research Conference 2014 http://www. esbri. se/june2014/diana. asp.

Foucault M. (1972).The archeology of knowledge. London: Tavistock.

Galloway, L., Kapasi, I., \& Sang, K. (2015). Entrepreneurship, Leadership, and the Value of Feminist Approaches to Understanding Them. Journal of Small Business Management, 53, 683-692.

Gartner, W. (1988). "Who is an entrepreneur?" is the wrong question. American Journal of Small Business, 12, 11-32.

Haagensen, K. M. (Ed.). (2014). Nordic Statistical Yearbook 2014. Copenhagen: Nordic Council Ministers.

Henry, C., Foss, L., \& Ahl, H. (2015). Gender and entrepreneurship research: A review of methodological approaches. International Small Business Journal, 0266242614549779.

Hernes, H. (1987). Welfare state and women power. Essays in state feminism. Oslo: Norwegian University Press.

Herring, C. (2009). Does diversity pay?: Race, gender, and the business case for diversity. American Sociological Review, 74(2), 208-224.

Hisrish, R. D., \& Brush, C. (1984). The woman entrepreneur: management skills and business problems. Journal of Small Business Management, 22, 30-37.

IEG World Bank Group. (2013). World Bank Group Support for Innovation and Entrepreneurship, An Independent Evaluation.

Jennings, J. E., \& Brush, C. G. (2013). Research on women entrepreneurs: challenges to (and from) the broader entrepreneurship literature? The Academy of Management Annals, 7, 663-715. 
Kroon Lundell, Å. (2012). Sminkad superhjältinna eller leende lagomföretagare? Företagarförebilder i pressen. (Info 0416). Stockholm: Tillväxtverket.

McCloskey, D. N. (2010). Bourgeois dignity: Why economics can't explain the modern world: University of Chicago Press.

Magnusson, E., Rönnblom, M., \& Silius, H. (2008). Critical Studies of Gender Equalities. Nordic dislocations, dilemmas and contradictions. Göteborg: Makadam.

Marlow, S. (2014). Exploring future research agendas in the field of gender and entrepreneurship. International Journal of Gender and Entrepreneurship, 6, 102-120.

Marlow, S., Shaw, E., \& Carter, S. (2008). Constructing female entrepreneurship policy in the UK: is the USA a relevant benchmark? Environmental Planning C: Government and Policy, 26, 335-351.

Martinsson, L., Griffin, G., \& Nygren, K. G. (Eds.) (2016). Challenging the Myth of Gender Equality in Sweden. Bristol: Policy Press.

Mayoux, L. (2001). Jobs, gender and small enterprises: getting the policy environment right. In Series on women's entrepreneurship development and gender in enterprises - WEDGE. Geneva: International Labour Office.

Mirchandani, K. (1999). Feminist insight on gendered work: New directions in research on women and entrepreneurship. Gender, Work \& Organization, 6(4), 224-235.

Nicholson, L., \& Anderson, A. R. (2005). News and Nuances of the Entrepreneurial Myth and Metaphor: Linguistic Games in Entrepreneurial Sense-Making and Sense-Giving. Entrepreneurship Theory and Practice, 29, 153-172.

Nilsson, P. (1997). Business counselling services directed towards female entrepreneurs - some legitimacy dilemmas. Entrepreneurship and Regional Development, 9, 239-258.

Niskanen, K. (2011). Gender and Power in the Nordic Countries: A Comparative Perspective. In K. Niskanen (Ed.), Gender and Power in the Nordic Countries (pp. 11-57). Oslo: NIKK.

Norden.statbank.dk/inco05, 3/10/16.

OECD. (n. d.). Women and men in OECD countries. Paris: OECD PUBLICATIONS.

Ogbor, J. O. (2000). Mythicizing and reification in entrepreneurial discourse: ideology-critique of entrepreneurial studies. Journal of Management Studies, 37, 605-635.

O'Reilly, J. (2006). Framing comparisons: gendering perspectives on cross-national comparative research on work and welfare. Work, Employment \& Society, 20, 731-750.

Pettersson, K. (2012). Support for women's entrepreneurship - A Nordic spectrum. International Journal of Gender and Entrepreneurship, 4, 4-19.

Pettersson, K., \& Lindberg, M. (2013). Paradoxical spaces of feminist resistance: mapping the margin to the masculinist innovation discourse. International Journal of Gender and Entrepreneurship, 5, 323-341.

Rouse, J., \& Kitching, J. (2006). Do enterprise support programmes leave women holding the baby? Environment and Planning C: Government and Policy, 24, 5-19.

Sainsbury, D. (1999). Gender and welfare state regimes. Oxford: Oxford University Press.

Sainsbury, D. (2001). Gender and the making of welfare states: Norway and Sweden. Social politics: international studies in gender, state \& society, 8(1), 113-143.

Sundin, E., \& Holmquist, C. (1989). Kvinnor som företagare. Osynlighet, mångfald, anpassning [Women entrepreneurs: invisibility, diversity, adjustment]. Malmö: Liber.

Storvik, A., \& Teigen, M. (2010). Women on board: The Norwegian experience. In FES International Policy Analysis. Berlin: Friedrich-Ebert-Stiftung.

Teigen, M. (2000). The affirmative action controversy. Nora: Nordic Journal of Women's Studies, 8(2), 63-77.

Teigen, M. (2011). Gender Quotas on Corporate Boards. In Niskanen (ed.) Gender and Power in the Nordic Countries - with a focus on politics and business, NIKK Publications 2011:1, (pp. 87-109). Oslo: Nordic Gender Institute (NIKK).

Teigen, M. (2012). Gender quotas on corporate boards: On the diffusion of a distinct national policy reform. In Engelstad \& Teigen, (Eds.), Firms, Boards and Gender Quotas: Comparative 
Perspectives (Comparative Social Research, Volume 29), (pp. 115-146). Bingley: Emerald Group Publishing Limited.

Tienari, J., Holgersson, C., Meriläinen, S., \& Höök, P. (2009). Gender, management and market discourse: The case of gender quotas in the Swedish and Finnish media. Gender, Work \& Organization, 16, 501-521.

Tillmar, M. (2007). Gendered small business assistance: lessons from a Swedish project. Journal of European Industrial Training, 31, 84-99.

UNdata. (2012). Gender Inequality Index. In (Vol. 2014): United Nations.

Verloo, M. (2005). Mainstreaming gender equality in Europe. A critical frame analysis approach. The Greek Review of Social Research, 117, 11-34.

Welter, F. (2011). Contextualising entrepreneurship: conceptual challenges and ways forward. Entrepreneurship Theory \& Practice, 35, 165-184.

Wilson, L., Whittam, G., \& Deakins, D. (2004). Women's enterprise: a critical examination of national policies. Environment and Planning C: Government and Policy, 22, 799-815.

Winther Jørgensen M., \& Phillips L. (2002). Discourse analysis as theory and method. London: Sage..

Wodak R., \& Meyer M. (2009). Methods of discourse analysis. Thousand Oaks: SAGE.

www.norden.org/en/fakta-om-norden-1/numbers-and-statistics, 03-10-16. 


\section{Appendix A}

Statistics on gender (in-)equalities in the Scandinavian countries.

Source: Haagensen (2014).

\begin{tabular}{|c|c|c|c|}
\hline & Denmark & Norway & Sweden \\
\hline $\begin{array}{l}\text { Population } \\
\text { (in millions) }\end{array}$ & 5, 627 (2014) & 5, 109 (2014) & 9, 644 (2014) \\
\hline $\begin{array}{l}\text { Candidates elected to } \\
\text { national parliament, latest } \\
\text { election: share of women } \\
\text { (\%) }\end{array}$ & 39 & 40 & 44 \\
\hline $\begin{array}{l}\text { Life expectancy women } \\
\text { (years) }\end{array}$ & 83 (2014) & 84 (2014) & 84 (2014) \\
\hline $\begin{array}{l}\text { Life expectancy men } \\
\text { (years) }\end{array}$ & 79 (2014) & 80 (2014) & 80 (2014) \\
\hline $\begin{array}{l}\text { Education: tertiary level } \\
\text { achieved: women, age 15- } \\
74 \text { years (\%) }\end{array}$ & 29 (2013) & 35 (2013) & 32 (2013) \\
\hline $\begin{array}{l}\text { Education: tertiary level } \\
\text { achieved: men, age 15-74 } \\
\text { years (\%) }\end{array}$ & 23 (2013) & 27 (2013) & 23 (2013) \\
\hline $\begin{array}{l}\text { Employment rate: women } \\
\text { 15-64 years (\%) }\end{array}$ & 70 (2013) & 73 (2013) & 72 (2013) \\
\hline $\begin{array}{l}\text { Employment rate: men } \\
\text { 15-64 years (\%) }\end{array}$ & 75 (2013) & 78 (2013) & 77 (2013) \\
\hline $\begin{array}{l}\text { Unemployment rate: } \\
\text { women } 15-64 \text { years (\%) }\end{array}$ & 7,4 (2013) & 3,4 (2013) & $8,0(2013)$ \\
\hline $\begin{array}{l}\text { Unemployment rate: men } \\
15-64 \text { years }(\%)\end{array}$ & 6,9 (2013) & 3,8 (2013) & $8,4(2013)$ \\
\hline $\begin{array}{l}\text { Part-time employment } \\
\text { rate }(<35 \text { hours/week): } \\
\text { women }(\%)^{4}\end{array}$ & 35 (2013) & 41 (2013) & 38 (2013) \\
\hline $\begin{array}{l}\text { Part-time employment } \\
\text { rate }(<35 \text { hours/week): } \\
\text { men }(\%)\end{array}$ & 15 (2013) & 14 (2013) & 12 (2013) \\
\hline $\begin{array}{l}\text { Average equivalent } \\
\text { disposable income: } \\
\text { women (PPP/Euro) }\end{array}$ & 20000 (2012) & $26500(2012)$ & 20250 (2012) \\
\hline $\begin{array}{l}\text { Average equivalent } \\
\text { disposable income: men } \\
\text { (PPP/Euro) }\end{array}$ & 20500 (2012) & 27500 (2012) & 21000 (2012) \\
\hline $\begin{array}{l}\text { Parental leave: percentage } \\
\text { taken by men (\%) }\end{array}$ & $\begin{array}{l}10,2 \\
(2013)\end{array}$ & $\begin{array}{l}21,2 \\
(2013)\end{array}$ & $\begin{array}{l}25,1 \\
(2013)\end{array}$ \\
\hline $\begin{array}{l}\text { Child care: per cent of the } \\
\text { 3-5 year-old children in } \\
\text { day care }(\%)\end{array}$ & 97 (2013) & 97 (2013) & 97 (2013) \\
\hline
\end{tabular}

\footnotetext{
${ }^{4}$ Activity rates are calculated as the number of people in the labour force between the ages of 15 and 64 as a percentage of all those between 15 and 64 years old (Haagensen, 2014)

${ }^{5}$ Purchasing power standards. The currency is converted from national currency to euro in Purchasing Power Standards (PPS), which eliminates the impact of differences in price levels across the Nordic countries (Haagensen, 2014).
} 


\title{
Appendix B:
}

\author{
Source Materials
}

Denmark

Danish Business Authority, Erhvervs- og Byggestyrelsen, 2009, Handlingsplan for Kvindelige Iværksættere.

Danish Business Authority, Erhvervs- og Byggestyrelsen, 2008, Kvinder kan - få succes med egen virksomhed.

Danish Business Authority, Erhvervsstyrelsen.dk/mission_vision, 17-03-14.

Danish Business Authority, Erhvervsstyrelsen.dk/maalrettede_indsatser, 20-02-14.

Godthaab, Nathalie and Kjær, Pernille, 2013, Slutrapport for projektet: Indsats for kvindelige ivœrksœttere (Kvinder Kan) Juli 2009 - marts 2013, Væksthus Syddanmark.

startvaekst.dk/file/293039/kvinder_Kan_ebog_bestyrelse_web.pdf, 18-03-14, Bestyrelse \& Advisory Bboard din adgang til vakst og viden (2012).

www.busiess.dk, 18-11-10.

www.erhvervsstyrelsen.dk, 02-02-16

www.evm.dk/om-ministeriet/organisation, 17-03-14.

www.vaekstguiden.dk/tilbud/0/7, 19-02-14.

\section{Norway}

Ministries, Departementa, Norge, 2008, Handlingsplan for meir entreprenørskap blant kvinner.

DevoTeamDaVinci, odat., Følgeevaluering av Kvinnovasjonsprogrammet i perioden 2009-2011.

kvinnovasjon.no, 06-05-14.

Ministry of Local Government and Modernisation, 2013a, Prop. 1 S, 2013-2014, Proposisjon til Stortinget [forslag til stortingsvedtak],

Ministry of Local Government and Modernisation, 2013b, Statsbudsjettet 2014 - Oppdragsbrev (to Innovation Norway).

Ministry of Local Government and Modernisation, 2014b, Statsbudsjettet 2015 - Tildelningsbrev til Norges Forskningsråd.

Ministry of Local Government and Modernisation 2016a, Statsbudsjettet 2016 - Tildelingsbrev til Norges Forskningsråd, Attachment RETNINGSLINJER FOR KAP. 552, POST 72 NASJONALE TILTAK FOR REGIONAL UTVIKLING.

Ministry of Local Government and Modernisation, 2015a, Statsbudsjettet 2015 - Oppdragsbrev til Innovasjon Norge.

Ministry of Local Government and Modernisation, 2016b, Statsbudsjettet 2016 - Oppdragsbrev (Innovation Norway)

Ministry of Local Government and Modernisation, 2013d, Statsbudsjettet 2014 - Oppdragsbrev til Siva SF.

Ministry of Local Government and Modernisation, 2016c; Statsbudsjettet 2016 - Oppdragsbrev til Siva SF.

Ministry of Local Government and Modernisation, 2015b, Statsbudsjettet 2015 - Oppdragsbrev til Siva SF.

Parliament notification, 2013, Meld. St 13, Ta heile Noreg i bruk, Distrikts- og regionalpolitikken.

Siva, 2013, SIVA beretter 2013.

siva.no/om-oss/?lang=en, 03-05-16.

www.forskningsradet.no/no/Utlysning/MER/1240290379474, 02-05-14.

www.innovasjonnorge.no/no/Om-Oss/omoss/\#.UzKvuMkV_cs, 26-03-14.

www.joconsulting.eu/en/successful-cases-of-eu-projects/257-ffemale-en, 25-04-14.

www.regjeringen.no/nb/dep/asd/dep/etatstyring/arbeids_og_velferdsetaten.html?id=1511, 14-05-14.

www.statsbudsjettet.no/Statsbudsjettet-2014/Dokumenter1/,26-03-14.

\section{Sweden}

Ramböll Management Consulting, 2013, Programmet Främja kvinnors företagande Mittutvärdering.

Ramböll, 2011, Slututvärdering kvinnors företagande.

The Government, 2007, Regeringsbeslut I 12, Sverige, 2007-05-10, N2007/4596/ENT (delvis) N2006/9663/ENT N2007/2432/ENT.

The Government, 2011, Regeringsbeslut, 2011-03-03, N2011/1250/ENT. Bilaga 1.

The Government, 2012, Regeringen, 2012, Bilaga till beslut 3 vid regeringens sammanträde den 8 mars 2012, N2012/1365/RT, Handlingsplan för en jämställd regional tillväxt 2012-2014.

The Swedish Agency for Economic and Regional Growth, 2015a, Ta täten! Lärdomar från kompetenshöjande insatser till företagsfrämjande aktörer, Slutrapport. 
The Swedish Agency for Economic and Regional Growth, 2015b, Utvärdering av sju pilotprojekt, Lärdomar från jämställdhetsintegrering av företagsfrämjande verksamhet, Slutrapport.

The Swedish Agency for Economic and Regional Growth, 2015c, Öppna Upp! Nationell strategi för ett företagsfrämjande på likvärdiga villkor 2015-2020, Info 0600.

The Swedish Agency for Economic and Regional Growth, 2015d, Open Up! National Strategy for Business Promotionon Equal Terms 2015-2020, Info 0606.

The Swedish Agency for Growth Analysis, 2014, Främja kvinnors företagande - Delrapport 1, Rapport 2014:05.

The Swedish Agency for Growth Analysis, 2013, Hur kan företagsstöden bli mer jämställda? Avrapportering enligt Regeringsbeslut N 2012/1368/RT, Rapport 0151.

The Swedish Agency for Growth Analysis, 2013, Vision: hållbar tillväxt, Hur kan kvinnors företagande integreras i tillväxtarbetet?

The Swedish Agency for Growth Analysis, 2007, Utfall och styrning av statliga insatser för kapitalförsörjning ur ett könsperspektiv, R 2007: 34.

The Swedish Agency for Growth Analysis, 2001, Att främja näringslivsutveckling - En framtidsinriktad utvärdering av affärsrådgivning för kvinnor, Nutek R 2001:3.

www.ambassadorer.se/wiki/on-webbplatsen, 10-04-09.

www.tillvaxtverket.se/huvudmeny/programfortillvaxt/framjakvinnorsforetagande.4.21099e4211fdba8c87b80001 6837.html, 10-04-12.

www.tillvaxtverket.se/huvudmeny/insatserfortillvaxt/flerochvaxandeforetag/framjakvinnorsforetagande/ambassa dorerforkvinnorsforetagande.4.74f57d0f1283a4f88ff80007488.html, 14-05-16.

www.tillvaxtverket.se/huvudmeny/insatserfortillvaxt/flerochvaxandeforetag/framjakvinnorsforetagande/faktaoch kunskap.4.74f57d0f1283a4f88ff80007477.html, 14-10-01.

www.tillvaxtverket.se/huvudmeny/insatserfortillvaxt/flerochvaxandeforetag/framjakvinnorsforetagande/goldenr ulesofleadership.4.2601af041445394dddccf0.html, 14-08-26.

www.tillvaxtverket.se/huvudmeny/insatserfortillvaxt/flerochvaxandeforetag/framjakvinnorsforetagande/meromp rogrammet/resultat20072010.4.74f57d0f1283a4f88ff80007499.html, 14-04-29.

www.tillvaxtverket.se/huvudmeny/insatserfortillvaxt/flerochvaxandeforetag/framjakvinnorsforetagande/meromp rogrammet.4.74f57d0f1283a4f88ff80007466.html, 06-05-12.

www.tillvaxtverket.se/huvudmeny/insatserfortillvaxt/flerochvaxandeforetag/framjakvinnorsforetagande/meromp rogrammet/fragorochsvar.4.74f57d0f1283a4f88ff800012051.html, 14-05-13.

www.tillvaxtverket.se/huvudmeny/insatserfortillvaxt/flerochvaxandeforetag/framjakvinnorsforetagande/meromp rogrammet/resultat20112012.4.276512151440f2f27b39cc.html, 14-05-12.

www.tillvaxtverket.se/huvudmeny/insatserfortillvaxt/flerochvaxandeforetag/framjakvinnorsforetagande/strategif orlikavillkor.4.1304101f13fcd69abab258.html, 14-05-16.

www.tillvaxtverket.se/huvudmeny/insatserfortillvaxt/flerochvaxandeforetag/framjakvinnorsforetagande/strategif orlikavillkor/tataten.4.1304101f13fcd69abab264.html, 14-05-16.

www.tillvaxtverket.se/huvudmeny/insatserfortillvaxt/regionalutveckling/jamstalldregionaltillvaxt/resurscentrafor kvinnor.4.21099e4211fdba8c87b800017797, 14-09-18.

www.tillvaxtverket.se, 03-03-16 a, www.tillvaxtverket.se/huvudmeny/omtillvaxtverket/resultat/avslutadeprogram/framjakvinnorsforetaga nde/resultat/affarsochinnovationsutveckling.4.74f57d0f1283a4f88ff80007414.html.

www.tillvaxtverket.se, 03-03-16 b, www.tillvaxtverket.se/huvudmeny/omtillvaxtverket/resultat/avslutadeprogram/framjakvinnorsforetaga nde/resultat/ambassadorerforkvinnorsforetagande.4.74f57d0f1283a4f88ff80007488.html 


\section{Appendix C}

List of key informants. The names have been removed for the sake of confidentiality.

\section{Denmark}

Key informant, Danish Business Authority, e-mail communication, 19-02-14.

Norway

Key informant, Innovation Norway, e-mail communication, 29-04-14.

Key informant, Ministry of Local Government and Modernisation, telephone interview, 26-02-14.

Key informant, Norwegian Research Council, e-mail communication, 14-04-30.

Key informant, Siva, e-mail communication, 06-05-14.

Key informant, Ministry of Children, Equality, and Social Inclusion, mail communication, 14-05-14.

Sweden

Key informant, The Swedish Agency for Economic and Regional Growth, telephone interview, 25-08-14.

Key informant, The Swedish Agency for Economic and Regional Growth, e-mail communication, 10-09-14. 